\title{
Particle Emissions from Domestic Gas Cookers
}

\section{Glarborg, Peter; Livbjerg, Hans; Wagner, Ayten Yilmaz; Kristensen, Per Gravers}

\section{Published in:}

Combustion Science and Technology

Link to article, DOI:

10.1080/00102202.2010.486015

Publication date:

2010

Document Version

Publisher's PDF, also known as Version of record

Link back to DTU Orbit

Citation (APA):

Glarborg, P., Livbjerg, H., Wagner, A. Y., \& Kristensen, P. G. (2010). Particle Emissions from Domestic Gas Cookers. Combustion Science and Technology, 182(10), 1511-1527.

https://doi.org/10.1080/00102202.2010.486015

\section{General rights}

Copyright and moral rights for the publications made accessible in the public portal are retained by the authors and/or other copyright owners and it is a condition of accessing publications that users recognise and abide by the legal requirements associated with these rights.

- Users may download and print one copy of any publication from the public portal for the purpose of private study or research.

- You may not further distribute the material or use it for any profit-making activity or commercial gain

- You may freely distribute the URL identifying the publication in the public portal 
This article was downloaded by: [Technical Knowledge Center of Denmark (DTIC)]

On: 6 October 2010

Access details: Access Details: [subscription number 912941598]

Publisher Taylor \& Francis

Informa Ltd Registered in England and Wales Registered Number: 1072954 Registered office: Mortimer House, 3741 Mortimer Street, London W1T 3JH, UK

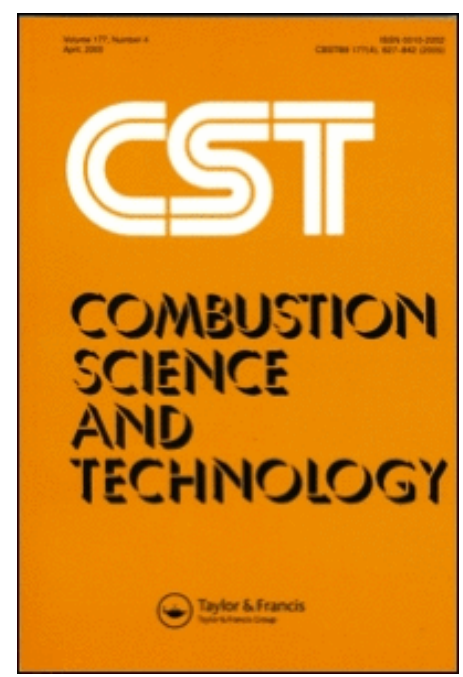

\section{Combustion Science and Technology}

Publication details, including instructions for authors and subscription information:

http://www.informaworld.com/smpp/title content=t713456315

\section{Particle Emissions from Domestic Gas Cookers}

Ayten Yilmaz Wagnera; Hans Livbjerga; Per Gravers Kristensen ${ }^{\mathrm{b}}$; Peter Glarborg ${ }^{\mathrm{a}}$

${ }^{a}$ Department of Chemical and Biochemical Engineering, Technical University of Denmark, Lyngby,

Denmark ${ }^{\mathrm{b}}$ Danish Gas Technology Center, Hørsholm, Denmark

Online publication date: 29 September 2010

To cite this Article Wagner, Ayten Yilmaz, Livbjerg, Hans, Kristensen, Per Gravers and Glarborg, Peter(2010) 'Particle Emissions from Domestic Gas Cookers', Combustion Science and Technology, 182: 10, 1511 - 1527

To link to this Article: DOI: 10.1080/00102202.2010.486015

URL: http://dx.doi.org/10.1080/00102202.2010.486015

\section{PLEASE SCROLL DOWN FOR ARTICLE}

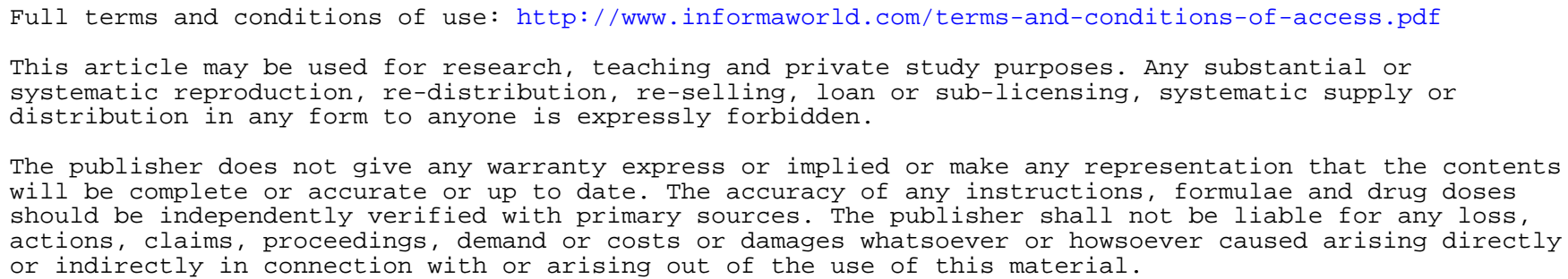




\title{
PARTICLE EMISSIONS FROM DOMESTIC GAS COOKERS
}

\author{
Ayten Yilmaz Wagner, ${ }^{1}$ Hans Livbjerg, ${ }^{1}$ \\ Per Gravers Kristensen, ${ }^{2}$ and Peter Glarborg ${ }^{1}$ \\ ${ }^{1}$ Department of Chemical and Biochemical Engineering, Technical University \\ of Denmark, Lyngby, Denmark \\ ${ }^{2}$ Danish Gas Technology Center, Hørsholm, Denmark
}

The authors experimentally studied the formation of submicron particles from a domestic gas cooker in a compartment free from external particle sources. The effects of fuel (methane, natural gas, odorant-free natural gas), primary aeration, flow rate, and fuel sulphur content on particle emissions were investigated. The experiments confirmed reports from literature that blue burning flames of domestic gas cookers emit submicron particles. The particle number concentrations varied in the range $10^{3}-10^{6}$ particles $/ \mathrm{cm}^{3}$, depending on the fuel, flow rate, and primary air addition. The diameters of the emitted particles were found to have a mean value of about $7 \mathrm{~nm}$ for partially premixed flames, increasing to $\sim 10 \mathrm{~nm}$ for nonpremixed flames. The quantity of primary air had a strong impact on the particle emissions, showing a minimum at a primary aeration level of 60-65\%. Presence of sulphur in small quantities may enhance particle formation under some conditions, but results were not conclusive.

Keywords: Aerosols; Gas cooker; Indoor air; Partially premixed flames; Soot

\section{INTRODUCTION}

In recent years, a growing body of scientific evidence has indicated that the air within homes and other buildings can be more seriously polluted than the outdoor air even in industrialized cities. Smoking, cooking, and infiltration of the polluted outdoor air have been the focus of several studies. Recently, particle emissions from cookers and stoves have attracted attention (Chahuan, 1999; Hänninen et al., 2004; Lewtas, 2007; Moshammer et al., 2006; Ning et al., 2006). In the last decade, even natural-gas-fired domestic cooktop burners have been identified as a source of particle emissions (Bang et al., 2004; Dennekamp et al., 2001; Minutolo et al., 2008; Murr et al., 2004a, 2004b; Murr and Soto, 2005). Dennekamp et al. (2001) measured concentrations of submicron particles of more than $10^{5}$ particles $/ \mathrm{cm}^{3}$ at face level over a gas cooker. The particles had a peak concentration for diameters in the range $15-40 \mathrm{~nm}$, increasing over time to about $50-70 \mathrm{~nm}$ while the gas rings were on.

Received 11 October 2009; accepted 13 April 2010.

Address correspondence to Peter Glarborg, Department of Chemical and Biochemical Engineering, Technical University of Denmark, DK-2800, Kgs. Lyngby, Denmark. E-mail: pgl@kt.dtu.dk 
The presence of larger carbon aggregates was confirmed in TEM studies by Murr and colleagues (Bang et al., 2004; Murr et al., 2004a, 2004b; Murr and Soto, 2005), who identified a range of carbon nanotubes and other concentric, fullerenic polyhedra in near-optimally burning blue flames.

Minutolo et al. (2008) conducted particle measurements on a natural-gas-fired domestic stove-top. Contrary to the findings of Dennekamp et al. (2001) and Murr and colleagues (Bang et al., 2004; Murr et al., 2004a, 2004b; Murr and Soto, 2005), Minutolo et al. (2008) measured only very small particles above the atmospheric air background, with a mean size of about $3 \mathrm{~nm}$. Minutolo et al. (2008) and D'Anna (2009) distinguished by size between two fundamental types of particles. Particles with sizes up to about $10 \mathrm{~nm}$ were termed molecular particle precursors and they are detectable by UV light absorption and laser-induced fluorescence (LIF). Particles larger than $10 \mathrm{~nm}$ were termed soot, and these particles are typically detected by visible light absorption and by laser-induced incandescence (LII) techniques. The sum of the two types of particles was termed total particulates. The results of Minutolo et al. (2008) indicate that the particles formed by the gas cooker are molecular precursor particles, rather than soot particles. The absence of soot particles is consistent with the blue flames associated with the cooktop burners. However, as indicated by occurrence of yellow flame colors, soot formation may be formed under conditions in which the flame flickers, promoted by the momentary interruptions in air flow (Murr and Soto, 2005).

The previous experiments on particle emissions from gas fired cooktop burners were conducted under conditions in which external particle sources or flow disturbances may have affected the results and contributed to the detection of larger particles. The objective of the present study was to characterize the particle emissions (particle number concentrations and particle sizes) from domestic gas cookers under ideal burning conditions and in an environment free from external particle sources. Particle concentrations and size distributions are detected as a function of fuel composition (methane or natural gas), fuel flow rate, and primary aeration. Although there are reports on the effects of primary aeration on the gaseous emissions from natural-gas-fired cooktop burners (Ashman et al., 1994; Ko and Lin, 2003; Li et al., 2006; Stubington et al., 1994; Stubington and Zou, 2000), these studies do not offer information regarding particle emissions. Furthermore, the role of trace amounts of sulphur in the fuel is investigated. Sulphur present in small amounts in natural gas may give rise to sulphuric acid aerosols or interact with the carbon particle formation (Glarborg, 2007).

\section{EXPERIMENTAL}

At present, the domestic gas burner most widely used is the conventional Bunsen type (i.e., partially aerated). Partially premixed flames are established when a less than stoichiometric quantity of oxidizer is premixed with the fuel stream before entering the reaction zone where additional oxidizer is available for complete combustion. The primary air-natural gas mixture flows into the bottom of the burner cap and issues from the burner through the burner ports, a large number of holes around the circumference of the burner cap (Stubington et al., 1994). The primary aeration is mostly in the range $40-60 \%$ of the stoichiometric air requirement, with 
a typical value for production cooktops of $\sim 50 \%$ (Stubington and Zou, 2000). This level of primary aeration results in short flames and prevents soot formation, resulting in the familiar blue flame. The maximum amount of primary air is limited by safety considerations.

The gas cooker used in the present study was inspected for $\mathrm{G} 20-2 \mathrm{H}$ type natural gas (i.e., with a gross Wobbe index in the range $51.9-55.8 \mathrm{MJ} / \mathrm{m}^{3}$ at $273 \mathrm{~K}$ ), supplied at a nominal supply pressure of 20 mbar. The gas hob of the cooker had a $3.3 \mathrm{~kW}$ rated heating capacity and $1200 \mathrm{~W}$ reduced flow rate. The burner consisted of three different rings with different nozzle sizes. The dimensions of the burner are presented in detail in Table 1. In the original kitchen range, the primary air was entrained by a jet of natural gas emerging from a small diameter injector into a mixing tube.

To ensure an environment free from external particle sources, the burner was placed in a reactor supplied with filtered air from its bottom. The air flow was controlled by a Krohne variable area flow meter, which provided flows in the range $0.085-0.85 \mathrm{~m}^{3} / \mathrm{min}$ (STP) with an accuracy of $\pm 1 \%$.

The reactor, presented in Figure 1, was composed of two compartments. In the lower compartment, the burner was placed at the bottom with the required gas connections and four ports, through which particle-free combustion air was supplied to the reactor. The ignition and flow control panel of the burner was kept outside the reactor, leaving the primary air supply nozzle inside the reactor. The combustion gases and additional air left the reactor through the exhaust at the top of the upper compartment, $80 \mathrm{~cm}$ above the burner.

In order to assure flame stability, the flow velocity through the reactor was kept below $10 \mathrm{~cm} / \mathrm{s}$, which is a representative median flow velocity in kitchens. The overall excess air ratio of the system was kept above 10. Glass windows placed at different heights allowed observation and video recording of the flame during experiments. A number of sampling ports allowed access at different vertical distances from the burner.

A typical partially aerated burner entrains primary air naturally by a momentum sharing process between the high-velocity gas jet and the ambient air (Ko and Lin, 2003). In this configuration, the amount of primary air cannot be regulated or measured easily. To study the effect of primary air on particle generation, it was important to control the primary air addition. For this reason, the original fuel-air supply nozzle of the burner was replaced in selected experiments with a mixing chamber, located outside the reactor. The chamber was designed to obtain a fast and efficient mixing of fuel and primary air in desired proportions before the gases

Table 1 Dimensions of the burner

\begin{tabular}{|c|c|c|c|c|c|}
\hline \multirow{2}{*}{$\begin{array}{l}\text { Variable } \\
\text { Burner ring diameter }(\mathrm{mm})\end{array}$} & \multirow{2}{*}{$\frac{\text { Outer nozzle }}{123,3}$} & \multicolumn{2}{|c|}{ Medium nozzle } & \multicolumn{2}{|c|}{ Inner nozzle } \\
\hline & & 85 & 80,9 & 31,0 & 33,0 \\
\hline Number of nozzles & 48 & 24 & 30 & 24 & 24 \\
\hline $\begin{array}{l}\text { Nozzle diameter }(\varnothing) \text { and bore } \\
\text { length }(\mathrm{L})(\mathrm{mm})\end{array}$ & $\begin{array}{c}\varnothing: 2,5 \\
\text { L: } 9\end{array}$ & $\begin{array}{c}ø: 1,3 \\
\mathrm{~L}: 7\end{array}$ & $\begin{array}{l}ø: 1,3 \\
\text { L: } 7\end{array}$ & $\varnothing: 1,1$ & $\varnothing: 1,1$ \\
\hline $\begin{array}{l}\text { Angle between nozzle bore } \\
\text { centerline and horizontal axis }\end{array}$ & $10^{\circ}$ & $45^{\circ}$ & $45^{\circ}$ & $10^{\circ}$ & $10^{\circ}$ \\
\hline
\end{tabular}




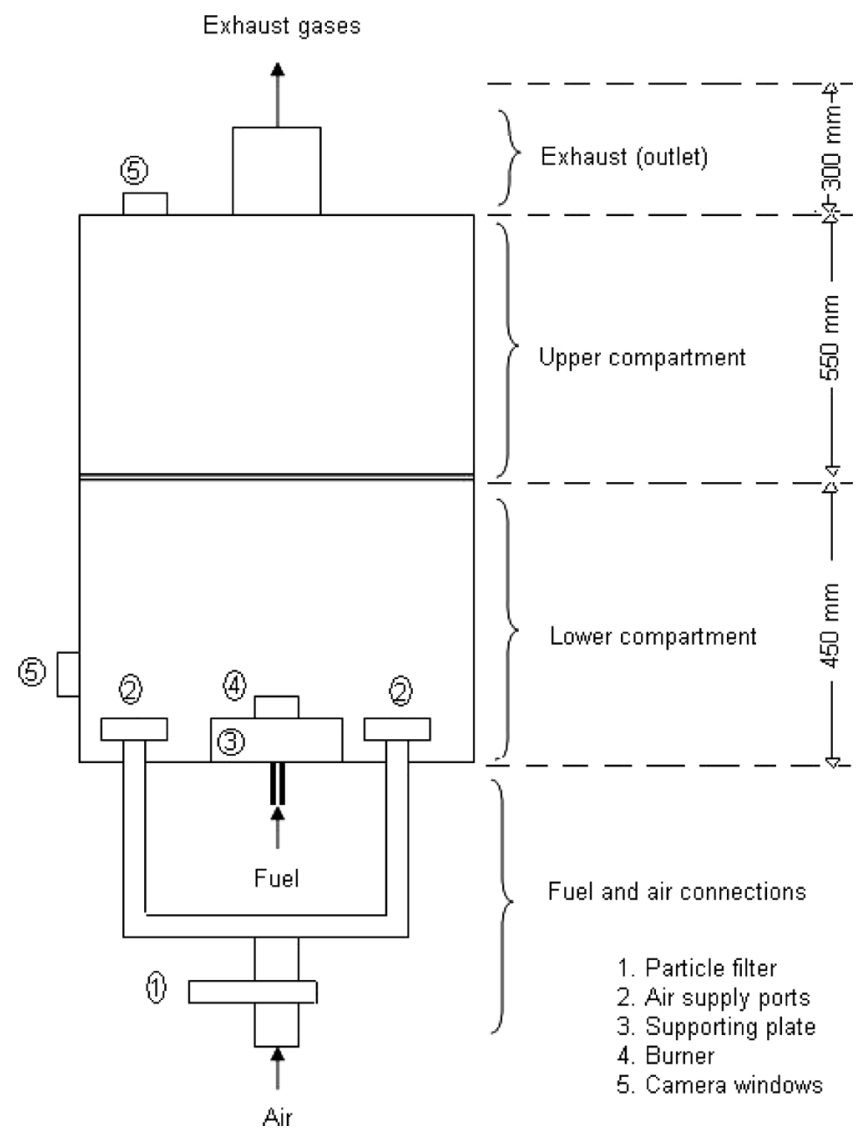

Figure 1 Schematic of the reactor.

were led to the burner. Bronkhorst High Tech El-flow mass flow controllers with capacities of $1.5,10$, and $80 \mathrm{~L} / \mathrm{min}(293 \mathrm{~K}, 5$ bar; accuracy $\pm 1 \%)$ were used to control the flows of fuel and primary air in these experiments. The uncertainty in the resulting primary aeration ratio is estimated to be $\pm 2 \%$.

Gas concentrations were measured at the sampling point located just below the reactor outlet $(80 \mathrm{~cm}$ above the burner; Figure 1$)$, using a steel probe $(\sim 2 \mathrm{~mm}$ in diameter). Analyzers included an ECO Physics CLD 700 EL chemiluminescence $\mathrm{NO} / \mathrm{NO}_{\mathrm{x}}$ analyzer and a Fisher-Rosemount MLT $\mathrm{CO} / \mathrm{CO}_{2} / \mathrm{O}_{2}$ analyzer. The uncertainty for the gas analyzers was $\pm 1 \%$ of the upper end of the measured range $\left(0-10 \mathrm{ppm} / \mathrm{v}\right.$ for $\mathrm{NO}_{\mathrm{x}}$; for $\mathrm{CO}$ in the range $0-10,0-100$, or $\left.0-1000 \mathrm{ppm} / \mathrm{v}\right)$. The uncertainty of the calibration gases used was $\pm 2 \%$. The $\mathrm{SO}_{2}$ concentration was below the detection limit of the available gas analyzers.

Particle concentrations were measured at the reactor exhaust, $110 \mathrm{~cm}$ above the burner, using a TSI Model 3775 Condensation Particle Counter (CPC). Particle concentration ranges that can be measured with this analyzer are $0-5 \cdot 10^{4}$ particles $/ \mathrm{cm}^{3}$ in the single-particle counting mode with continuous, live-time coincidence correction, and $5 \cdot 10^{4}-10^{7}$ particles $/ \mathrm{cm}^{3}$ in the photometric mode. The instrument switched 
Table 2 Settings of SMPS system for scanning different size ranges

\begin{tabular}{lcccc}
\hline DMA model & $\begin{array}{c}\text { Theoretical size } \\
\text { range }(\mathrm{nm})\end{array}$ & $\begin{array}{c}\text { Aerosol flow } \\
(\mathrm{L} / \mathrm{min})\end{array}$ & $\begin{array}{c}\text { Sheath flow } \\
(\mathrm{L} / \mathrm{min})\end{array}$ & $\begin{array}{c}\text { Impactor nozzle } \\
(\mathrm{cm})\end{array}$ \\
\hline 3081 LDMA & $13-833$ & 0.3 & 3,0 & 0.0457 \\
& $9.0-469$ & 0.6 & 6,0 & 0.0457 \\
3085 NDMA & $5.7-239$ & 1.5 & 15 & 0.071 \\
& $4.4-168$ & 0.3 & 3,0 & 0.0457 \\
& $3.1-111$ & 0.6 & 6,0 & 0.0457 \\
& $2.0-66$ & 1.5 & 15 & 0.071 \\
\hline
\end{tabular}

automatically between operation modes. The measurement accuracy was $\pm 10 \%$ at $<5 \cdot 10^{4}$ particles $/ \mathrm{cm}^{3}$ and $\pm 20 \%$ at $<10^{7}$ particles $/ \mathrm{cm}^{3}$. The minimum and maximum detectable particles $\left(D_{50}\right)$ were $4 \mathrm{~nm}$ and $>3 \mu \mathrm{m}$, respectively.

Particles were classified with a TSI Model 3080 Electrostatic Classifier with a TSI Model 3081 LDMA (Long Differential Mobility Analyzer) and a TSI Model 3085 NDMA (Nano Differential Mobility Analyzer). The maximum input concentration for both DMAs was limited to $10^{8}$ particles $/ \mathrm{cm}^{3}$ at $10 \mathrm{~nm}$, whereas the aerosol temperature should be in the range $10-40^{\circ} \mathrm{C}$. The particle size ranges that could be detected were $10-1000 \mathrm{~nm}$ with 3081 LDMA and 4-150 nm with 3085 NDMA. The analyzers were calibrated for a monodisperse aerosol consisting of polystyrene particles with a diameter of $102 \pm 3 \mathrm{~nm}$. Furthermore, measurements for a polydisperse $\mathrm{NaCl}$ aerosol $(10-300 \mathrm{~nm})$ compared well with data obtained by similar equipment at University of Copenhagen for both size distribution and maximum number concentration. Table 2 provides an overview of the instrument settings required for detecting different size ranges. The actual size range measured depends on temperature, pressure, gas type, and scan time. In our experiments, first the wide range $(10-1000 \mathrm{~nm})$ was scanned, followed by a scan over narrower range $(4-150 \mathrm{~nm})$.

Because the SMPS system imposes limits on the aerosol temperature and particle number concentrations, the sample gas from the reactor outlet needed to be cooled and diluted. In order to meet this need, a gas ejector probe developed for fine particle analysis (Johannesen et al., 2000) was used. The ejector dilution also served to lower the water dew point of the aerosol and thus prevent condensation. Dilution ratios of 10-20 were used in our experiments. They were determined as the ratio of particle number concentrations in the ambient air measured by direct sampling to the particle number concentrations in the ambient air measured by sampling with the ejector probe. These measurements were performed for sufficiently long time (i.e., $10 \mathrm{~min}$ each) to minimize any artefacts caused by activities ongoing in the surroundings. In order to prevent deposition due to electrostatic forces in the sampling lines, tubes made of carbonized silicon material were used as sampling lines between the ejector probe and the SMPS.

\section{RESULTS AND DISCUSSION}

Experiments were performed with three different fuels: methane, natural gas, and odorant-free natural gas. The gases were supplied from the city pipeline (natural gas) or from gas cylinders with known compositions (natural gas, odorant-free 
Table 3 Composition of natural gas and odorant-free natural gas

\begin{tabular}{lcc}
\hline Variable & Natural gas $(\%$ vol $)$ & Odorant-free natural gas $(\%$ vol $)$ \\
\hline Methane & 88.80 & 88.81 \\
Ethane & 5.70 & 5.71 \\
Propane & 2.24 & 2.26 \\
Butane & 0.88 & 0.93 \\
Pentane & 0.20 & 0.22 \\
Hexane & 0.049 & 0.066 \\
$\mathrm{CO}_{2}$ & 0.7 & 0.7 \\
$\mathrm{~N}_{2}$ & 0.3 & 0.3 \\
\hline
\end{tabular}

natural gas, methane). The impurities in the methane cylinder as reported by our supplier were $\mathrm{O}_{2}<30 \mathrm{ppm}, \mathrm{H}_{2}<20 \mathrm{ppm}, \mathrm{N}_{2}<200 \mathrm{ppm}$, and $\mathrm{C}_{\mathrm{x}} \mathrm{H}_{\mathrm{y}}<300 \mathrm{ppm}$. The composition of natural gas and odorant-free natural gas were analyzed as shown in Table 3. The odorant-free natural gas contained $2-4 \mathrm{mg} / \mathrm{m}^{3} \mathrm{~S}$, whereas the sulphur content of the natural gas was about $10 \mathrm{mg} / \mathrm{m}^{3}$.

The experiments were carried out using air flow rates of $400 \mathrm{~L} / \mathrm{min}$ and fuel flow rates in the range $0.9-4.4 \mathrm{~L} / \mathrm{min}$ (STP). In all experiments, before igniting the flame, the reactor was purged with filtered air. The particle number concentration measured at the reactor outlet during the flush-off process was around 100 particles $/ \mathrm{cm}^{3}$, and neither $\mathrm{CO}$ nor $\mathrm{NO}_{\mathrm{x}}$ was detected. As soon as the flame was ignited, a sharp peak was observed in $\mathrm{CO}$ and particle number concentrations. Concentrations then decreased and the reactor reached steady-state conditions within $\sim 50$ min after ignition.

\subsection{Effect of Fuel and Fuel Flow Rate}

In order to identify effects of the fuel and the fuel flow rate on the combustion and particle emissions, experiments were conducted with natural gas (from the city pipeline) and methane (from a cylinder), using the same procedure. Figure 2 shows $\mathrm{CO}$ emissions measured for methane and natural gas, respectively, at different fuel flow rates. For both fuels, $\mathrm{CO}$ emissions were considerably higher in the low flow rate experiments, indicating that the burner operated more efficiently at fuel flow rates larger than $4 \mathrm{~L} / \mathrm{min}$. Differences in $\mathrm{CO}$ emissions from the two fuels were within the experimental scatter. The $\mathrm{NO}_{\mathrm{x}}$ emissions measured at different fuel flow rates are presented in Figure 3. For both fuels, nitrogen oxides emissions increased with increasing fuel flow rate. Combustion of natural gas yielded higher $\mathrm{NO}_{\mathrm{x}}$ concentrations compared to methane experiments.

Steady-state particle number concentrations as function of fuel and fuel flow rate are shown in Figure 4. The measured number concentrations showed a large variation, particularly at larger fuel flow rates. For natural gas, particle number concentrations varied in the range $3 \cdot 10^{4}-5 \cdot 10^{5}$ particles $/ \mathrm{cm}^{3}$, whereas for methane the scatter was even larger, with concentrations ranging from $1 \cdot 10^{3}-2 \cdot 10^{5}$ particles $/ \mathrm{cm}^{3}$. An effect of the fuel flow rate, if any, is hidden within the scatter in the data.

Figure 5 shows particles size distributions collected during combustion. Particles detected prior to combustion were few $\left(\sim 100\right.$ particles $\left./ \mathrm{cm}^{3}\right)$ and fairly large 


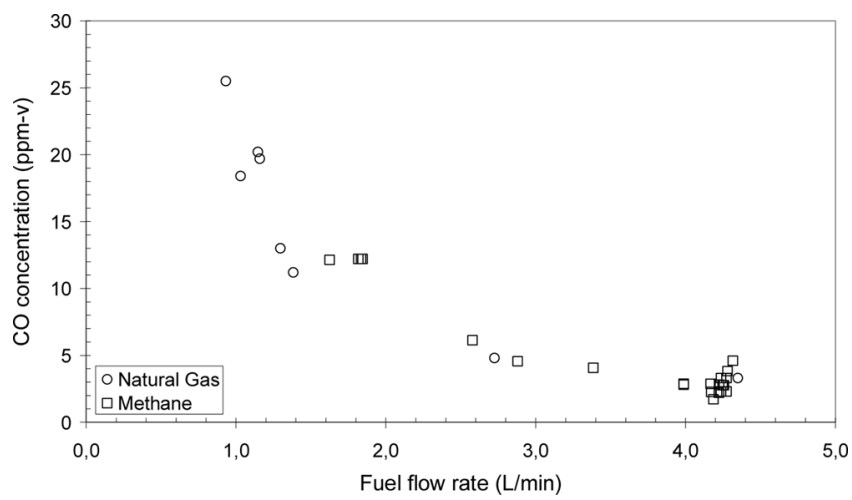

Figure 2 Concentrations of $\mathrm{CO}$ measured at $80 \mathrm{~cm}$ above the burner for experiments conducted with methane (from gas cylinder) and natural gas (from the city line).

$(>80 \mathrm{~nm})$. They did not show any particular size distribution trend, but rather appeared as few peaks. Once combustion started (using natural gas), these particles remained, but became almost negligible in terms of number concentrations compared to the combustion generated particles, which had a single mode size distribution with a mean diameter of $\sim 7 \mathrm{~nm}$. After turning off the flame, the initially observed particles, which were larger than $80 \mathrm{~nm}$, appeared again as a few peaks.

A comparison between the diameters of particles generated from methane and natural gas was desired. However, the size data collected from the methane experiments seemed to be incomplete, indicating that the particles generated from methane fell below the measurement range of $4.5-160 \mathrm{~nm}$. The size range of particles detected in the methane and natural gas experiments supports the findings of Minutolo et al. (2008), whereas the large particles or aggregates $\left(D_{p}>20 \mathrm{~nm}\right)$ reported by Dennekamp et al. (2001), Bang et al. (2004), Murr et al. (2004a, 2004b), and Murr and Soto (2005) were not observed.

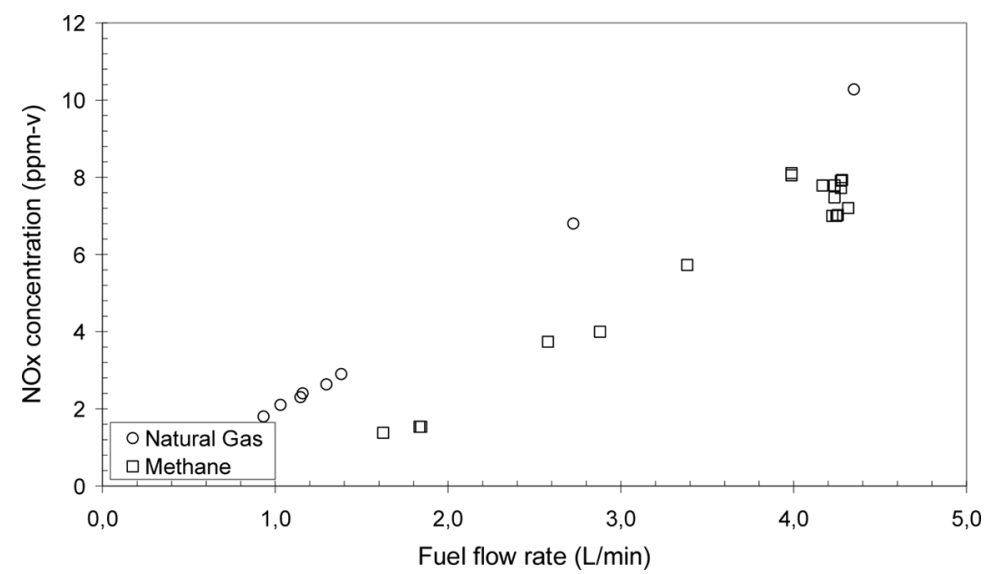

Figure 3 Concentrations of $\mathrm{NO}_{\mathrm{x}}$ measured at $80 \mathrm{~cm}$ above the burner for experiments conducted with methane (from gas cylinder) and natural gas (from the city line). 


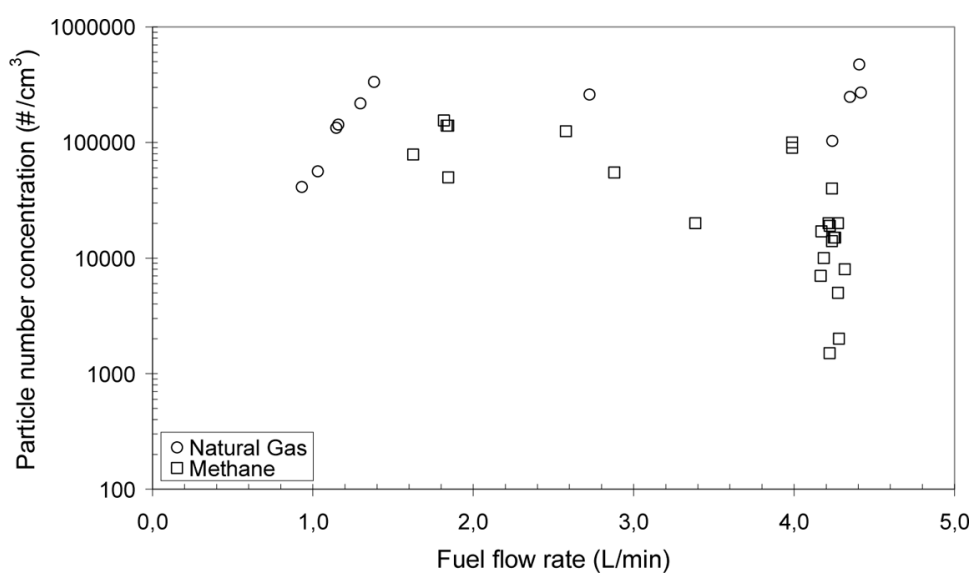

Figure 4 Particle number concentrations measured at the reactor outlet for experiments conducted with methane (from gas cylinder) and natural gas (from the city line). The CPC was used at a low flow rate of $0.3 \pm 0.015 \mathrm{~L} / \mathrm{min}$. The minimum detectable particle $\left(\mathrm{D}_{50}\right)$ is $4 \mathrm{~nm}$ and the maximum detectable particle $\left(\mathrm{D}_{50}\right)$ is $>3 \mu \mathrm{m}$.

\subsection{Effect of Primary Air Ratio}

As discussed previously, the primary aeration of cooktop burners is mostly in the range $40-60 \%$ of the stoichiometric air requirement. The lower limit is the occurrence of yellow-tipping due to incomplete combustion (insufficient oxygen in the premix), whereas the upper limit is the lift or blow-off limit when the velocity of

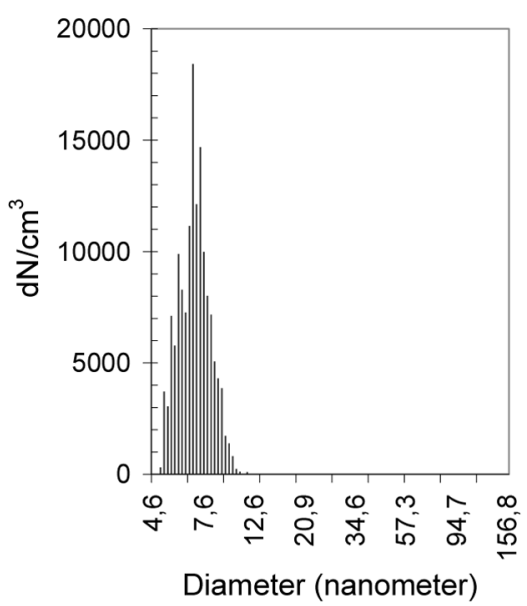

(a)

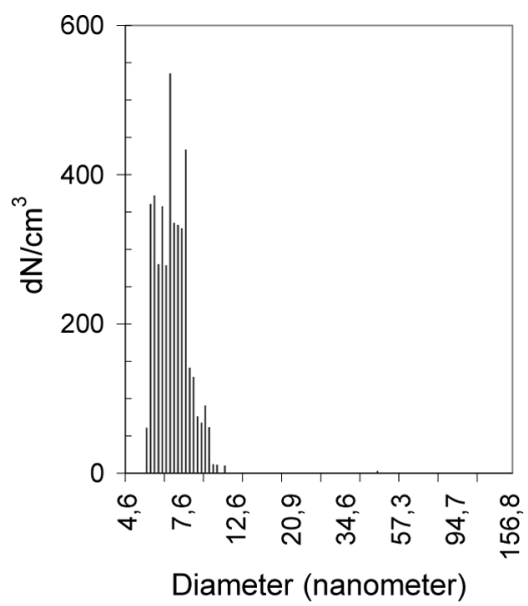

(b)

Figure 5 Particle size distributions during combustion of natural gas (city line) supplied to the reactor with gas flow rates of (a) $1.38 \mathrm{~L} / \mathrm{min}$ and (b) $4.42 \mathrm{~L} / \mathrm{min}$. The SMPS settings allowed measurements in the range $4.53-159.6 \mathrm{~nm}$. The total particle concentrations are $1.5 \mathrm{E} 5$ and $4.3 \mathrm{E} 3$ particles $/ \mathrm{cm}^{3}$, respectively. Settings sheath flow $=3 \mathrm{~L} / \mathrm{min}$; aerosol flow $=0.3 \mathrm{~L} / \mathrm{min}$; impactor type $=0.0457 \mathrm{~cm}$; scan up time $=120 \mathrm{~s}$; retrace time $=15 \mathrm{~s}$. 
the premixed gas through the burner ports exceeds the burning velocity of the mixture (Stubington and Zou, 2000).

The primary air ratio of the burner would be expected to be important for the formation of submicron carbon particles. This parameter was investigated for methane and natural gas, using the external mixer to adjust the flow rate of the primary air. The ratio $(\mathrm{R})$ of primary air supply to the stoichiometric air requirement of the studied fuel was maintained independent of fuel.

Figure 6 shows visual observations for different primary aeration levels with natural gas as a fuel, recorded using a webcam. The condition of $\mathrm{R}=0$ corresponds to pure natural gas issuing from the burner nozzles. In this case, a long, unsteady diffusion flame is formed. As the primary aeration increases toward the recommended operating range of $40-60 \%$ primary aeration, the flames become shorter and more stable. Addition of more than $80 \%$ of the stoichiometric air requirement as primary air resulted in less stable and eventually extinguished flames. At high levels of primary aeration, close to stoichiometric, a large fraction of the cooktop burner flames were blown off, resulting in decreasing particle number concentrations. The point of extinction occurred at primary air flow rates corresponding to $88 \%$ of the stoichiometric air requirement.

Figures 7 and 8 show the emissions of $\mathrm{CO}$ and $\mathrm{NO}_{\mathrm{x}}$, respectively, as a function of fuel and primary aeration. For both species, the concentrations are seen to depend on the primary aeration level, whereas the impact of fuel (methane or natural gas) is within the scatter. Figure 7 shows that the $\mathrm{CO}$ emission is roughly constant for $\mathrm{R}=0.2-0.7$. For $\mathrm{R}>0.7$, the $\mathrm{CO}$ level rises sharply, peaking at $\mathrm{R}=0.8$ at values 1-2 orders of magnitude higher than the minimum concentration. At close to stoichiometric conditions ( $\mathrm{R} \sim 1)$, the $\mathrm{CO}$ level is still high, even though the burner is partially extinguished. For comparison, Li et al. (2006) reported CO emissions for primary air ratios in the range $0.5-0.7$; in agreement with our observations, they

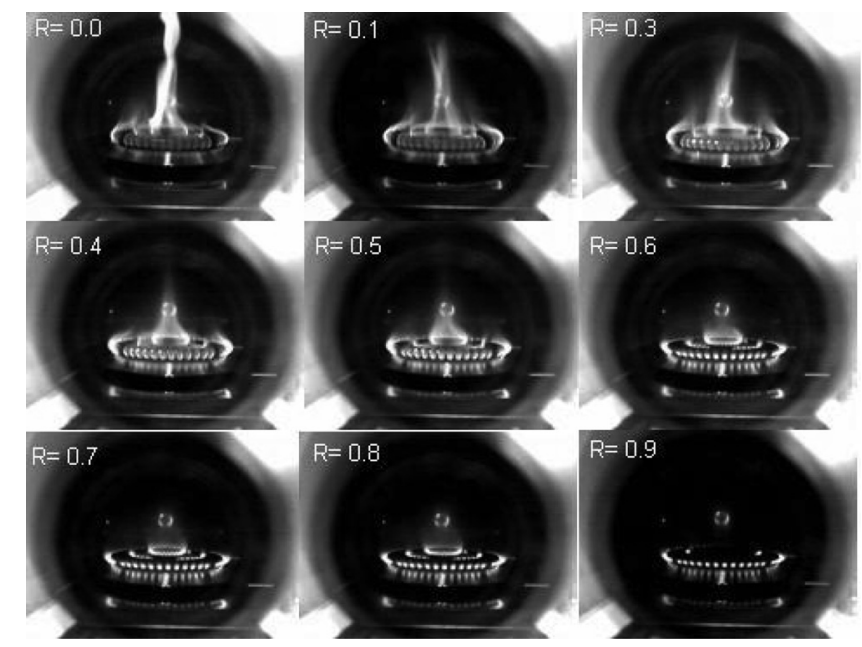

Figure 6 Images of the flame at different primary aeration levels. The natural gas flow rate was $4 \mathrm{~L} / \mathrm{min}$, delivered from a cylinder. $\mathrm{R}$ denotes the ratio of primary air flow rate to the stoichiometric air requirement. 


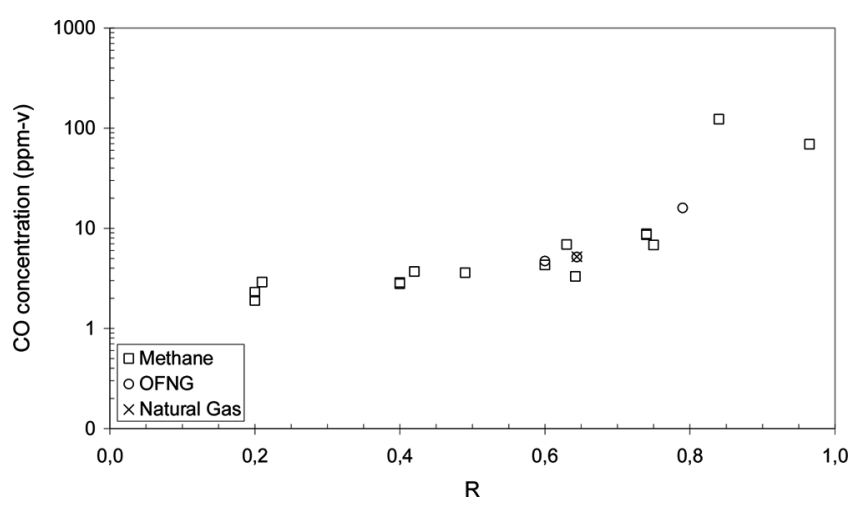

Figure $7 \mathrm{CO}$ concentrations generated at a fuel flow rate of $4.0 \mathrm{~L} / \mathrm{min}$ with different fuels and at different primary air flow rates. All gases were supplied from gas cylinders with known compositions.

found the $\mathrm{CO}$ to be a weak function of $\mathrm{R}$ in this range. The sharp increase in $\mathrm{CO}$ for $\mathrm{R}>0.7$ in the present setup indicates that the flames become less stable as they approach extinguishment. The emission of $\mathrm{NO}_{\mathrm{x}}$ (Figure 8) exhibits a minimum at $\mathrm{R} \approx 0.5-0.6$. Results for $\mathrm{R}>0.8$ are not shown because here the $\mathrm{NO}_{\mathrm{x}}$ concentrations exceeded the calibrated range of the gas analyzer $(0-10 \mathrm{ppm} / \mathrm{v})$.

Figure 9 shows the impact of fuel and primary aeration on the particle generation. The results show that the particle number concentrations were influenced by the amount of primary air supplied as well as by the fuel. The minimum particle emissions were observed at values of $\mathrm{R}$ of $65-70 \%$ (methane) and $60-65 \%$ (natural gas), respectively. At $\mathrm{R}$ values higher or lower than this point, particle emissions increased, with peak values of $10^{5}-10^{6}$ particles $/ \mathrm{cm}$ detected in the range $0 \leq \mathrm{R} \leq 0.4$ (i.e., for the pure diffusion flame $[\mathrm{R}=0]$ and partially premixed flames with low primary stoichiometries). At the extinction point of $\mathrm{R}=0.88$, the particle emission decreases dramatically as a significant fraction of the fuel escapes the burner unreacted.

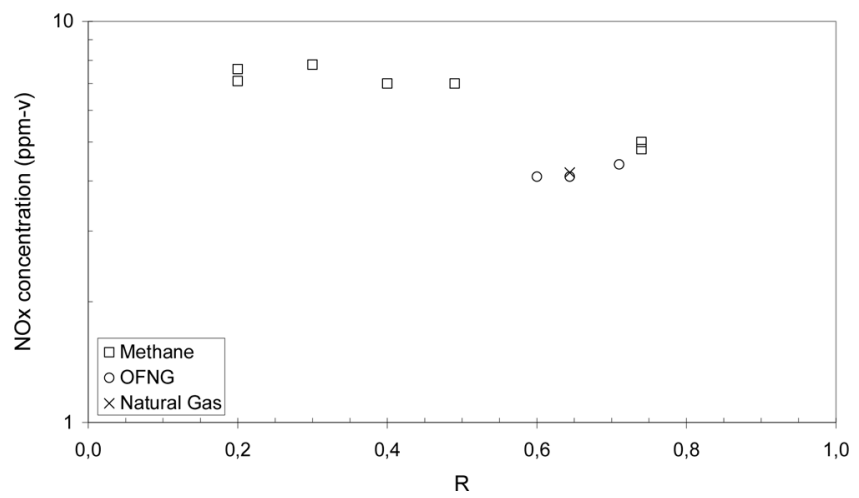

Figure $8 \mathrm{NO}_{\mathrm{x}}$ concentrations generated at a fuel flow rate of $4.0 \mathrm{~L} / \mathrm{min}$ with different fuels and at different primary air flow rates. All gases were supplied from gas cylinders with known gas compositions. 


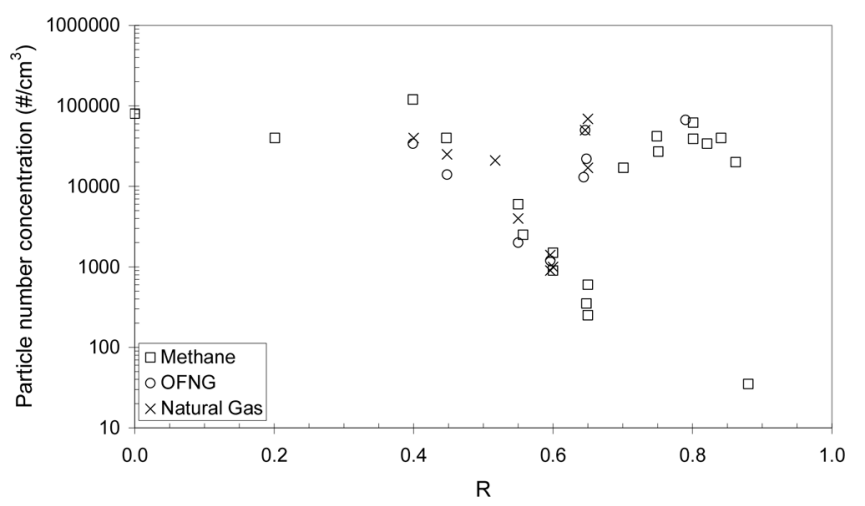

Figure 9 Particle number concentrations generated at a fuel flow rate of $4.0 \mathrm{~L} / \mathrm{min}$ with different fuels and at different primary air flow rates. All gases were supplied from gas cylinders with known gas compositions. The CPC was used at a low flow rate of $0.3 \pm 0.015 \mathrm{~L} / \mathrm{min}$.

It is noteworthy that small variations in $\mathrm{R}$ around values of 0.6 cause changes in the particle concentrations of more than two orders of magnitude. Conceivably, the large scatter in particle yields observed with the original fuel-air supply nozzle of the burner (Figure 4) can be attributed to small fluctuations in the primary air intake to the burner. The present results also indicate that the operating point of the original burner was not optimal with respect to particle emissions. From Figure 9 , it is seen that levels of $10^{3}$ particles $/ \mathrm{cm}^{3}$ should be achievable by fine-tuning the burner. However, the present method of aeration (i.e., natural entrainment of primary air by a momentum sharing process) may not be sufficiently accurate or stable to obtain this aim.

The size distribution data for the particles generated in the methane diffusion flame are presented in Figure 10. The mean diameter of the particles from this flame was around $10 \mathrm{~nm}$. This is consistent with the diffusion flame being the only visibly sooting flame (Figure 6). The partially premixed flames, even those close to extinguishment, are all blue and the corresponding particle sizes are well below $10 \mathrm{~nm}$. This is in agreement with the findings of Minutolo et al. (2008).

The reason for the minimum in particle number densities at primary aeration levels of $60-70 \%$ cannot be fully resolved based on the present data, but some insight may be gained from results on premixed and partially premixed methane flames reported in literature. D'Anna et al. (2008) measured organic carbon and soot particles in premixed methane flames. Methane forms a significantly lower amount of particles than unsaturated hydrocarbons such as ethylene. D'Anna et al. (2008) reported mainly organic carbon particles with diameters of 3-10 nm; soot was only formed at very high $\mathrm{C} / \mathrm{O}$ ratios. The particle formation decreased monotonically with the excess air ratio in the range $0.4 \leq \lambda \leq 0.67$, but particles were still detected close to stoichiometric conditions. These observations are in good agreement with the present findings.

The formation of soot particles as a function of the primary aeration in partially premixed laminar flames has been studied previously, both in coflow (Arana et al., 2004; Du et al., 1990; Gulder, 1995; McEnally and Pfefferle, 2002) and in 


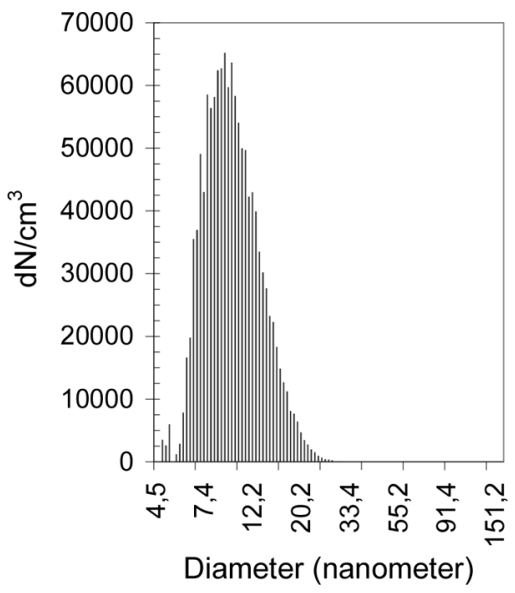

Figure 10 Size distribution data of particles emitted from diffusion flame of $4.26 \mathrm{~L} / \mathrm{min}$ methane. The SMPS settings allowed measurements in the range $4.37-165.4 \mathrm{~nm}$. The total particle concentration is $1.28 \mathrm{E} 6$ particles $/ \mathrm{cm}^{3}$. Sheath flow $(\mathrm{L} / \mathrm{min})=3$; aerosol flow $(\mathrm{L} / \mathrm{min})=0.3$; impactor type $(\mathrm{cm})=0.0457$; scan up time $(s)=300$; retrace time $(s)=15$.

counterflow (Du et al., 1990; Mungekar and Atreya, 2006a, 2006b) configurations. Premixing of air with the fuel may affect particle formation through both physical mechanisms (changes in residence time, temperatures, and fuel concentration) and through chemical effects (Du et al., 1990; Gulder, 1995; McEnally and Pfefferle, 2002). The physical effects tend to decrease soot formation independent of fuel type, whereas the chemical effects seem to be fuel specific (McEnally and Pfefferle, 2002). Fuel dilution and oxidative consumption of particle precursors would be expected to inhibit soot formation independent of burner configuration, whereas flow and temperature effects may be burner specific. Air is a stronger inhibitor of carbon particle formation than $\mathrm{O}_{2}$ at comparable stoichiometries due to the additional fuel dilution induced by the $\mathrm{N}_{2}$.

For methane, addition of $\mathrm{O}_{2}(0-16 \%$ of the fuel stream) serves to inhibit soot formation (Gulder, 1995). This finding is in agreement with the observation of reduced concentrations of soot precursors such as $\mathrm{C}_{2} \mathrm{H}_{2}$, as well as of higher hydrocarbons, with increasing primary aeration in partially premixed methane flames (Bennett et al., 2000; McEnally and Pfefferle, 1999). For unsaturated hydrocarbons such as ethylene and acetylene, addition of oxygen in low concentrations to the fuel stream has been reported to enhance the soot yield (Arana et al., 2004; Du et al., 1990; McEnally and Pfefferle, 2002), presumably because the $\mathrm{O}_{2}$ promotes formation of precursors to aromatic species. At higher primary aeration levels, the soot yield decreases (Du et al., 1990). An enhancing effect of $\mathrm{O}_{2}$ has also been observed for propane and n-butane, but only at higher oxygen levels (Du et al., 1990; Gulder, 1995).

The results from premixed methane flames indicate that the particle formation, both molecular particle precursors and soot, decreases monotonically with increasing oxygen content (D'Anna et al., 2008). The observations reported from partially premixed methane flames show the same trend, but they apply to soot and may not be representative for the molecular particle precursors $(2-10 \mathrm{~nm})$ from cooktop 
burners. The increased particle number concentrations above primary aeration levels of $65-70 \%$ observed in the present work have to our knowledge not been reported previously. Because $\mathrm{O}_{2}$ in larger concentrations serves to oxidize and thereby eliminate both soot and soot precursors, the increased particle yield is unlikely to be a chemical effect. Rather, the impact may be attributed to a physical mechanism, most likely the shortened residence time due to higher gas velocities. It is likely that the increased particle number concentrations for primary aeration levels above $65-70 \%$ are caused by the increased strain of the flames as they approach the blow-off limit. However, temperature effects may also be important and more work is required to resolve this issue.

\subsection{Effect of Trace Amounts of Sulphur}

Natural gas contains some amount of sulphur in the form of $\mathrm{H}_{2} \mathrm{~S}$. As $\mathrm{H}_{2} \mathrm{~S}$ is both a health hazard and a cause of corrosion in gas pipes, natural gas containing more than about $15 \mathrm{ppm}$ of $\mathrm{H}_{2} \mathrm{~S}$ is purified before distribution and domestic consumption. However, when the natural gas is delivered for distribution to the customers, a sulphurous smelling substance - an odorant - is added in order to ensure that the otherwise odorless gas can be detected by anyone in the near vicinity in the event of a gas leak. Odorants such as tetrahydrothiophenes or mercaptans typically account for more than $50 \%$ of the sulphur compounds in distributed natural gas (Hennings and Reumert, 2007).

Presence of sulphur is of interest partly because it may give rise to formation of sulphuric acid aerosols and partly because it is known to affect soot formation (Glarborg, 2007). The predominant product formed by the combustion of sulphur compounds is sulphur dioxide. Even when oxygen is present in large stoichiometric excess, sulphur trioxide is seldom found in amounts greater than a few percent of the total sulphur oxides (Cullis and Mulcahy, 1972; Glarborg et al., 1996; Jørgensen et al., 2007). Nevertheless, although the concentrations of sulphur trioxide expected in the flue gas from gas cookers are well below $1 \mathrm{ppm}$, it may give rise to nonnegligible levels of sulphuric acid aerosols, and the presence of sulphur in particles collected from domestic gas cookers was reported by Murr et al. (2004a).

In addition to forming sulphuric acid aerosols, sulphur may affect the carbon particle formation. Results from premixed hydrocarbon flames (Lawton, 1989) show that the presence of $\mathrm{SO}_{2}$ causes a decrease in the soot volume fraction and particle diameter, whereas the number density and the coagulation rate are unaffected. The data indicate that $\mathrm{SO}_{2}$ enhances the oxidation of soot once formed, presumably by a direct reaction with the particle. In diffusion flames (Cotton et al., 1971; Gulder, 1993; Schug et al., 1980; Wolfhard and Parker, 1950), adding $\mathrm{SO}_{2}$ on the fuel or oxidizer side causes a reduction in the soot yield, but the effect is small and may be attributed to dilution and thermal effects.

Figure 9 compares the particle number concentrations for combustion of natural gas and odorless natural gas. Even though the odorless gas yields slightly lower particle concentrations under conditions with primary air ratios below $65 \%$, the difference is within the experimental uncertainty and the results are not conclusive. In order to investigate the impact of sulphur species on particle emissions from the burner further, additional tests were conducted by adding $\mathrm{H}_{2} \mathrm{~S}$ to methane. Because $\mathrm{H}_{2} \mathrm{~S}$ 


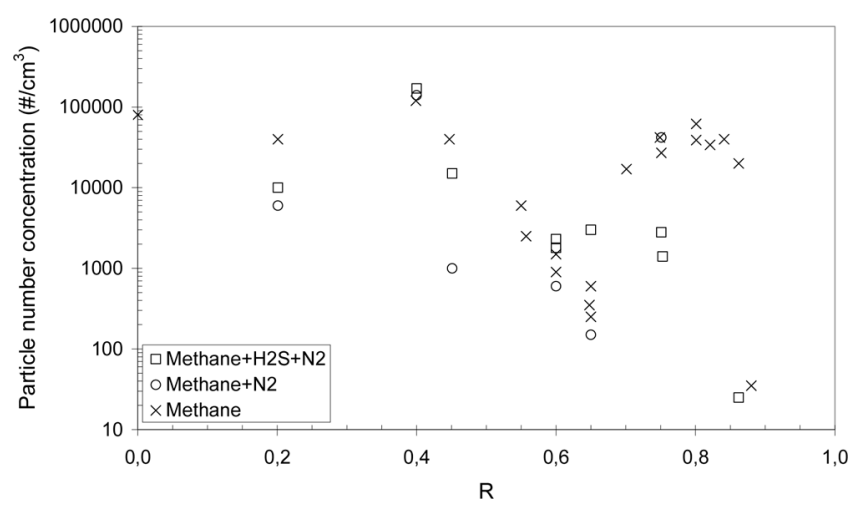

Figure 11 Effect of addition of $\mathrm{N}_{2}$ and $\mathrm{H}_{2} \mathrm{~S}$ on particle number concentrations. The methane flow rate in all experiments is kept as $4 \mathrm{~L} / \mathrm{min}$. All gases were supplied from gas cylinders with known gas compositions. CPC was used at low flow rate, $0.3 \pm 0.015 \mathrm{~L} / \mathrm{min}$. Particle concentration accuracy is $\pm 10 \%$ at $<5 \times 10^{4}$ particles $/ \mathrm{cm}^{3}, \pm 20 \%$ at $<10^{7}$ particles $/ \mathrm{cm}^{3}$.

was supplied heavily diluted in nitrogen, the addition of $\mathrm{H}_{2} \mathrm{~S}$ resulted in dilution of the fuel flow with $\mathrm{N}_{2}$. The resulting fuel composition was $91.2 \% \mathrm{CH}_{4}, 8.8 \% \mathrm{~N}_{2}$, and $100 \mathrm{ppm} \mathrm{H}_{2} \mathrm{~S}$. In order to distinguish between the additive effect and the dilution effect on the particle emissions, reference experiments were conducted with a $91.2 \%$ $\mathrm{CH}_{4} / 8.8 \% \mathrm{~N}_{2}$ mixture without sulphur.

The results of the sulphur addition experiments are presented in Figure 11. Comparison of the data for methane and diluted methane indicates that at least for $\mathrm{R}$ values of $65 \%$ and lower, the nitrogen dilution results in a slight lowering of the particle formation. This is an expected result because dilution is known to be a means to reduce carbon particle formation in flames. The impact of sulphur is seen from comparing the diluted methane data with those for sulphur addition. Similarly to Figure 9, the presence of sulphur appears to enhance particle formation for $\mathrm{R} \leq 65 \%$, but again the difference is too small to be conclusive. Also for $\mathrm{R}$ values of $70 \%$ and higher, the data material is inconclusive.

From the data, it cannot be ruled out that the presence of sulphur in the fuel, even in trace quantities, enhances particle formation at $\mathrm{R} \approx 65 \%$ and lower (i.e., in the normal operating regime for these burners). Sulphur may give rise to formation of sulphuric acid aerosols, or it may interact with the hydrocarbon precursor chemistry or with the particles directly. However, the present results are not conclusive and further work is desirable.

\section{CONCLUSIONS}

The present experiments performed with methane, natural gas, and odorantfree natural gas showed that blue burning flames of domestic gas cookers emit particles and that these emissions are very sensitive to primary air addition. The diameters of the particles emitted were found to be below $10 \mathrm{~nm}$ for these partially premixed flames, in agreement with the soot precursor particles identified by Minutolo et al. (2008). At similar flow rates and primary aeration, combustion of 
methane, natural gas, and odorant-free natural gas resulted in comparable particle number concentrations. The minimum particle emissions were observed at primary aeration levels of $65-70 \%$ for methane and $60-65 \%$ for natural gas, with or without the odorant. These ranges are above the typical primary aeration range for commercial domestic gas cooktop burners. The increase in particle concentrations at primary aeration levels of more than $65-70 \%$ is attributed to the increased strain of the flames as they approach the blow-off limit. However, more work is required to resolve this issue. Presence of trace amounts of sulphur may promote particle formation, but the present results are not conclusive.

\section{ACKNOWLEDGMENTS}

This work was carried out at the Department of Chemical and Biochemical Engineering at the Technical University of Denmark (DTU). The work was cofinanced by DTU, Danish Gas Technology Center (DGC), and Danish Ministry of Science, Technology and Innovation. The authors would like to thank Michael Heiredal and Merete Bilde for helpful discussions and assistance with verifying the SMPS measurements.

\section{REFERENCES}

Arana, C.P., Pontoni, M., Sen, S., and Puri, I.K. 2004. Field measurements of soot volume fraction in laminar partially premixed coflow ethylene/air flames. Combust. Flame, 138, $362-372$.

Ashman, P.J., Junus, R., Stubington, J.F., and Sergeant, G.D. 1994. The effect of load height on the emissions from a natural-gas fired domestic gas cook-top burner. Combust. Sci. Technol., 103, 283.

Bang, J.J., Guerrero, P.A., Lopez, D.A., Murr, L.E., and Esquivel E.V. 2004. Carbon nanotubes and other fullerene nanocarystals in domestic propane and natural gas combustion streams. J. Nanosci. Nanotechnol., 4, 716-718.

Bennett, B.A.V., McEnally, C.S., Pfefferle, L.D., and Smooke, M.D. 2000. Computational and experimental study of axisymmetric coflow partially premixed methane/air flames. Combust. Flame, 123, 522-546.

Chauhan, A.J. 1999. Gas cooking appliances and indoor pollution. Clinic. Exp. Allergy, 29, 1009-1013.

Cotton, D.H., Friswell, N.J., and Jenkins, D.R. 1971. The suppression of soot emission from flames by metal additives. Combust. Flame, 17, 87-98.

Cullis, C.F., and Mulcahy, M.F.R. 1972. The kinetics of combustion of gaseous sulphur compounds. Combust. Flame, 18, 225-292.

D’Anna, A. 2009. Combustion formed nanoparticles. Proc. Combust. Inst., 32, 593-613.

D’Anna, A, Sirignano, M., Commodo, M., Pagliara, R., and Minutolo, P. 2008. An experimental and modelling study of particulate formation in premixed flames burning methane. Combust. Sci. Technol., 180, 950-958.

Dennekamp, M., Howarth, S., Dick, C.A.J., Cherriea, J.W., Donaldson, K., and Seaton, A. 2001. Ultrafine particles and nitrogen oxides generated by gas and electric cooking. Occup. Env. Medicine, 58, 511-516.

Du, D.X., Axelbaum, R.L., and Law, C.K. 1990. The influence of carbon dioxide and oxygen as additives on soot formation in diffusion flames. Proc. Combust. Inst., 23, 1501-1507. 
Glarborg, P. 2007. Hidden interactions-Trace species governing combustion and emissions. Proc. Combust. Inst., 31, 77-98.

Glarborg, P., Kubel, D., Dam-Johansen, K., Chiang, H.M., and Bozzelli, J.W. 1996. Impact of $\mathrm{SO}_{2}$ and $\mathrm{NO}$ on $\mathrm{CO}$ oxidation under post-flame conditions. Int. J. Chem. Kin., 28, 773-790.

Gulder, O.L. 1993. Influence of sulfur dioxide on soot formation in diffusion flames. Combust. Flame, 92, 410-418.

Gulder, O.L. 1995. Effects of oxygen on soot formation in methane, propane, and n-butane diffusion flames. Combust. Flame, 101, 302-310.

Hänninen, O.O., Lebret, E., Ilacqua, V., Katsouyanni, K., Künzli, N., Srám, R.J., and Jantunen, M. 2004. Infiltration of ambient PM2.5 and levels of indoor generated non-ETS PM2.5 in residences of four European cities. Atm. Environ., 38, 6411-6423.

Hennings, U., and Reimert, R. 2007. Behaviour of sulphur-free odorants in natural gas fed PEM fuel cell systems. Fuel Cell, 7, 63-69.

Johannessen, J.T., Pratsinis, S.E., and Livbjerg, H. 2000. Computational fluid-particle dynamics for the flame synthesis of alumina particles. Chem. Eng. Sci., 55, 177-191.

Jørgensen, T.L., Livbjerg, H., and Glarborg, P. 2007. Homogeneous and heterogeneously catalyzed oxidation of $\mathrm{SO}_{2}$. Chem. Eng. Sci., 62, 4496-4499.

Ko, Y.C., and Lin, T.H. 2003. Emissions and efficiency of a domestic gas stove burning natural gases with various compositions. Energy Conv. Man., 44, 3001-3014.

Lawton, S.A. 1989. The effect of sulfur dioxide on soot and polycyclic aromatic hydrocarbon formation in premixed ethylene flames. Combust. Flame, 75, 175-181.

Lewtas, J. 2007. Air pollution combustion emissions: Characterization of causative agents and mechanisms associated with cancer, reproductive, and cardiovascular effects. Mutation Res., 636, 95-133.

Li, H.B., Wong, T.T., Leung, C.W., and Probert, S.D. 2006. Thermal performances and CO emissions of gas-fired cooker-top burners. Appl. Energy, 83, 1326-1338.

McEnally, C.S., and Pfefferle, L.D. 1999. Experimental study of nonfuel hydrocarbon concentrations in coflowing partially premixed methane/air flames. Combust. Flame, 118, 619-632.

McEnally, C.S., and Pfefferle, L.D. 2002. The effects of premixing on soot production in non-premixed flames fuelled with unsaturated hydrocarbons. Proc. Combust. Inst., 29, 2407-2413.

Minutolo, P., D’Anna, A., Commodo, M., Pagliara, R., Toniato, G., and Accordini, C. 2008. Emission of ultrafine particles from natural gas domestic burners. Env. Eng. Sci., 25, $1357-1364$.

Moshammer, H., Hutter, H.P., and Neuberger, M. 2006. Gas cooking and reduced lung function in school children. Atm. Environ., 40, 3349-3354.

Mungekar, H.P., and Atreya, A. 2006a. Flame radiation and soot emission from partially premixed methane counterflow flames. J. Heat Transfer, 128, 361-367.

Mungekar, H.P., and Atreya, A. 2006b. Effect of partial premixing on the sooting structure of methane flames. Combust. Flame, 144, 336-348.

Murr, L.E., Bang, J.J., Esquivel, E.V., Guerrero, P.A., and Lopez, D.A. 2004a. Carbon nanotubes, nanocrystal forms, and complex nanoparticle aggregates in common fuel-gas combustion sources and the ambient air. J. Nanoparticle Res., 6, 241-251.

Murr, L.E., Bang, J.J., Lopez, D.A., Guerrero, P.A., Esquivel, E.V., Choudhuri, A.R., Subramanya, M., Morandi, M., and Holian A. 2004b. Carbon nanotubes and nanocrystals in methane combustion and the environmental implications. J. Mater. Sci., 39, 199-204.

Murr, L.E., and Soto, K.F. 2005. A TEM study of soot, carbon nanotubes, and related fullerene nanopolyhedra in common fuel-gas combustion sources. Mater. Charac., 55, 50-65. 
Ning, Z., Cheung, C.S., Fu, J, Liu, M.A., and Schnell, M.A. 2006. Experimental study of environmental tobacco smoke particles under actual indoor environment. Sci. Total Env., 367, 822-830.

Schug, K.P., Manheimer-Timnat, Y., Yaccarino, P., and Glassman, I. 1980. Sooting behaviour of gaseous hydrocarbon diffusion flames and the influence of additives. Combust. Sci. Technol., 22, 235-250.

Stubington, J.F., Beashel, G., Murphy, T., Junus, R., Ashman, P.J., and Sergeant, G.D. 1994. Emissions and efficiency from production cooktop burners firing natural gas. J. Inst. Energy, 67, 143-155.

Stubington, J.F., and Zou, W. 2000. Efficient low-emission burners for natural gas domestic cooktops. J. Inst. Energy, 73, 35-42.

Wolfhard, H.G., and Parker, W.G. 1950. Influence of sulphur on carbon formation in diffusion flames. Fuel, 29, 235-240. 